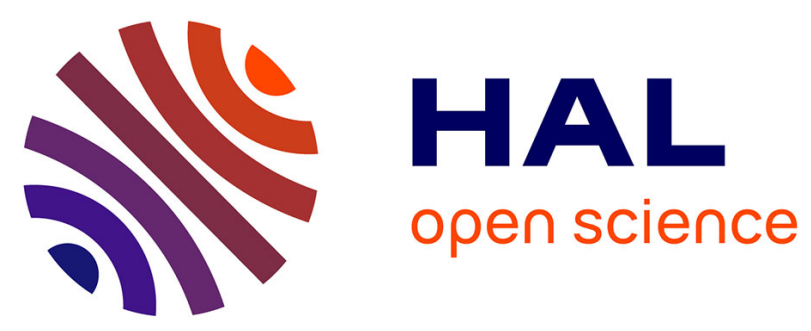

\title{
Using image-based size analysis for determining the size distribution and flux of eolian particles sampled in coastal northern Chile (23 degrees $\mathrm{S}$ )
}

Valentina Flores-Aqueveque, Sandrine Caquineau, Stéphane Alfaro, Jorge Valdés, Gabriel Vargas

\section{To cite this version:}

Valentina Flores-Aqueveque, Sandrine Caquineau, Stéphane Alfaro, Jorge Valdés, Gabriel Vargas. Using image-based size analysis for determining the size distribution and flux of eolian particles sampled in coastal northern Chile (23 degrees S). Journal of Sedimentary Research, 2014, 84 (3-4), pp.238-244. $10.2110 /$ jsr.2014.23 . ird-01052774

\section{HAL Id: ird-01052774 \\ https://hal.ird.fr/ird-01052774}

Submitted on 28 Jul 2014

HAL is a multi-disciplinary open access archive for the deposit and dissemination of scientific research documents, whether they are published or not. The documents may come from teaching and research institutions in France or abroad, or from public or private research centers.
L'archive ouverte pluridisciplinaire HAL, est destinée au dépôt et à la diffusion de documents scientifiques de niveau recherche, publiés ou non, émanant des établissements d'enseignement et de recherche français ou étrangers, des laboratoires publics ou privés. 


\title{
USING IMAGE-BASED SIZE ANALYSIS FOR DETERMINING THE SIZE DISTRIBUTION AND FLUX OF EOLIAN PARTICLES SAMPLED IN COASTAL NORTHERN CHILE $\left(23^{\circ} \mathrm{S}\right)$
}

\author{
VALENTINA FLORES-AQUEVEQUE,,${ }^{1,2}$ SANDRINE CAQUINEAU, ${ }^{3}$ STEPHANE ALFARO,${ }^{2}$ JOR GE VALDÉS,${ }^{4}$ AND GABRIEL VARGAS \\ ${ }^{1}$ Departamento de Geología, Facultad de Ciencias Físicas y Matemáticas, Universidad de Chile, Plaza Ercilla 803, Santiago, Chile \\ ${ }^{2}$ LISA, UMR CNRSIINSU 7583, Universités de Paris-Est Créteil et Paris-Diderot, 61 avenue du General de Gaulle, Créteil, France \\ ${ }_{3}^{3}$ IPSL/LOCEAN, UPMCICNRS/IRDIMNHN, Centre IRD France Nord, 32 avenue Henri Varagnat, 93143 Bondy CEDEX, France \\ ${ }^{4}$ Laboratorio de Sedimentología y Paleoambientes (LASPAL), Instituto de Ciencias Naturales Alexander von Humboldt, Facultad de Ciencias del Mar y de Recursos \\ Biológicos, Universidad de Antofagasta, Laboratorio Mixto Internacional PALEOTRACES, IRD-UA-UFF, Avenida Universidad de Antofagasta s/n, Antofagasta, Chile \\ e-mail:v.flores.a@gmail.com
}

\begin{abstract}
The aim of this study was to determine the size distribution and flux of the mineral fraction collected in marine sediment traps in Mejillones Bay (23 $\mathrm{S}$ ) using image-based size analysis. In this bay the material settling in the water column is a mixture of biogenic particles and lithic grains. The sediments analyzed correspond to four samples collected in the austral spring of 2008. We used image-based size analysis because it presents several advantages, which makes it an ideal method to study fine marine sediments. This analysis also yielded important information about the aspect and the morphology of the particles. In order to analyze the lithic fraction only, different pretreatments were applied and size - analyses were carried out with and without image information. Besides the main lithic components (quartz, feldspar, amphiboles, and micas), some nonlithic particles corresponding mainly to organic-matter remains were observed in the images, showing that the pretreatment was not fully effective. Biogenic silica and unexpected dark particles of probable anthropogenic origin were also detected. To avoid the influence of nonlithic grains in the analysis, the images were filtered based on the aspect of the particles using various discrimination tools. Before and after this removal, the size distributions of the samples were estimated and used to calculate the total flux. As compared to the flux of lithic particles, this total flux displays a systematic overestimation of up to $12 \%$. As a consequence, using image-based size analysis allows not only enhancing the determination of the size distribution and flux but also controlling and improving the pretreatments protocols.
\end{abstract}

\section{INTRODUCTION}

The assessment of particulate-matter size distributions based on image analysis is an underutilized tool in environmental disciplines, despite its great potential for characterizing such fine material as marine or lacustrine sediments, ashes, loess, and particles of eolian origin (e.g., Frančišković-Bilinski et al. 2003; Buurman et al. 2001). Conventional methods, using the measurement of sedimentation velocities in water, such as the settling methods based on Stokes' law have several drawbacks. Their results depend on the laboratory technique, and even on the operator. They are also time-consuming, have a limited sizeresolution capacity, and require large amounts of material (10-20 g for the pipette method and $40 \mathrm{~g}$ for the hydrometer; Eshel et al. 2004). In contrast, size measurements based on image analysis are fast, precise and replicable, allow the analysis of very small samples $(<1 \mathrm{mg})$, and provide a very good size resolution.

Comparisons of the results provided by classical methods with those of more recent technologies (laser diffraction, hydrophotometer, Coulter counter, etc.) indicate that differences may be attributable mostly to the morphology and mineralogical composition of the particles (e.g., Beuselinck et al. 1998; Eshel et al. 2004; Frančišković-Bilinski et al. 2003; Konert and Vanderberghe 1997). Indeed, because classical methods assume that the particles are spherical and have a uniform mass density equal to quartz, settling methods yield equivalent diameters. For prolate particles, or for mixtures of particles with different densities, these equivalent-sphere size distributions can hardly be considered as representative of the actual size distributions. Discrepancies between idealized and real size distributions can be even greater when significant interparticle morphological differences are involved. Indeed, nonspherical particles tend to sediment with their largest section perpendicular to the direction of their fall (Krumbein 1942), which increases the resistance of the fluid to their movement, reduces their falling velocity (Matthews 1991), and eventually leads to an overestimation of their size. This bias does not occur for results derived from image analysis. On the contrary, analyses based on images can provide important information on the morphology of particles, and therefore about their genesis, subsequent transport, and depositional processes.

This study presents the results of the analyses performed on particles collected in marine sediment traps installed in the Mejillones Bay $\left(23^{\circ} \mathrm{S}\right)$ (Fig. 1), which is located near an important upwelling center of the coastal Atacama Desert of northern Chile (Rodríguez et al. 1991; Rutllant et al. 1998; Marín and Olivares 1999; Marín et al. 2003). We focused on the determination of the characteristics of the mineral particles, the objective being to characterize their size distribution and quantify the flux of wind-transported particles being deposited at the sea surface. To do that, pretreatments were applied to the samples in order to remove the nonlithic particles. After this, a size analysis based on images was used in two ways. For the first approach the images displayed by the 

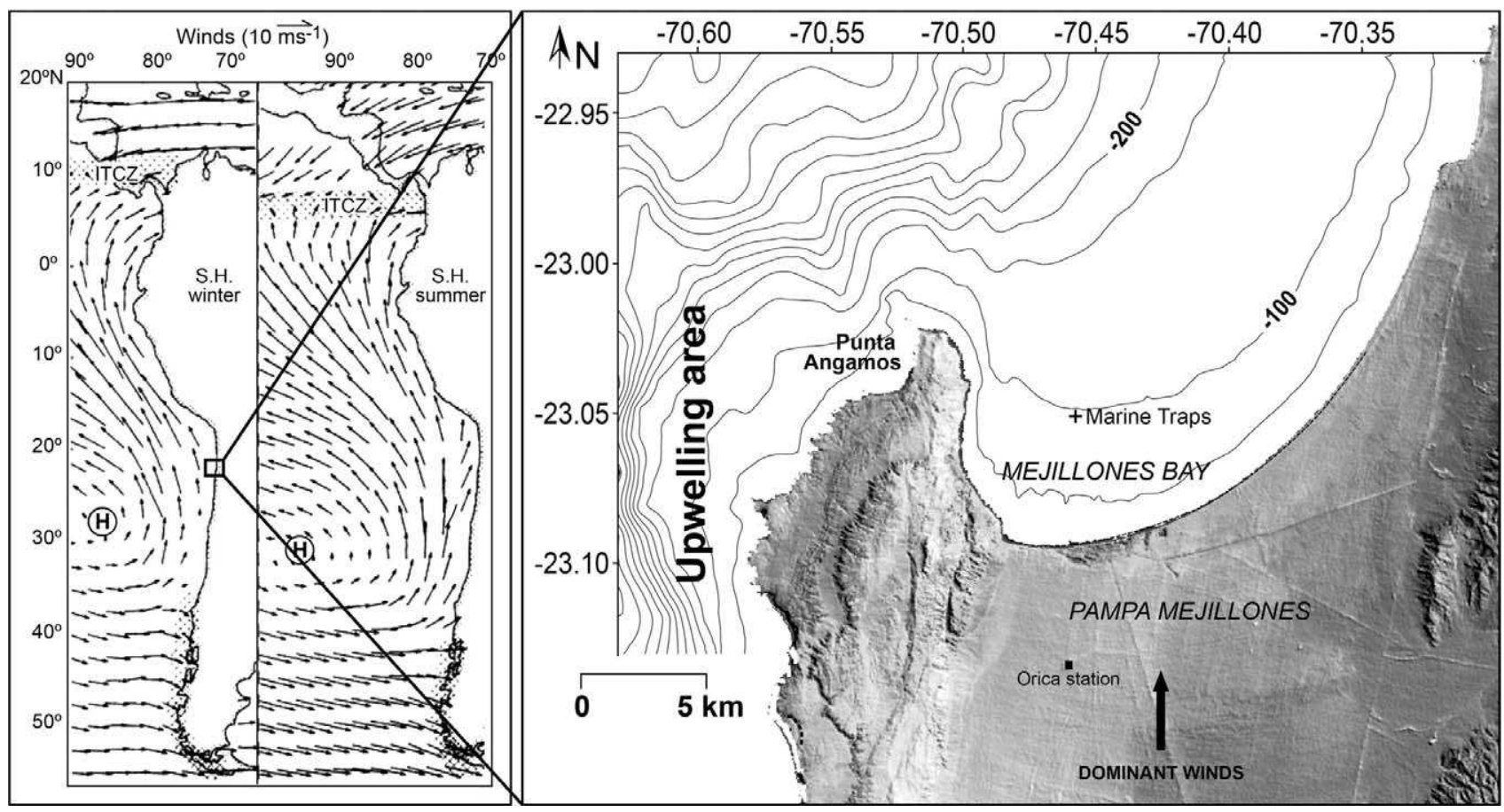

FIG. 1.-Location of the experimental site. Left panel: The subtropical anticyclone $(\mathrm{H})$ and associated surface winds over the southeast Pacific (modified from Strub et al. 1998) (S.H.: Southern Hemisphere). Right panel: Map of the Mejillones Peninsula on which the location of the marine trap, bathymetry, and the main geomorphological features are reported.

system are ignored and therefore results are similar to those obtained, for example, with a laser granulometer. In the second method the images are used to recognize and eliminate, if necessary, nonlithic particles. The preparation of the samples and the techniques used are explained in detail in the "Methods" section. The "Results and Discussion" section summarizes the results of the particle size distributions and flux analyses for the original pretreated series and the filtered (only lithic particles) data. The last section presents a comparison between both methodologies and highlights the implication for visualizing the particles to improve results and for adapting the protocols of the applied pretreatments.

\section{METHODS}

\section{Study Area}

Along the coast of Northern Chile, the dryness (rainfall $<4 \mathrm{~mm}$ year ${ }^{-1}$ ) induced by the subtropical anticyclone is enhanced by the presence of the Andes (Rutllant et al. 2003; Muñoz 2008), the cold waters of the Humboldt Current system (Strub et al. 1998), and coastal upwelling events driven all year round by southerly winds (Strub et al. 1998; Rutllant et al. 1998). In spring and summer, the high frequency of clear skies combined with the greatest influence of the anticyclone leads to an intensification of these winds along the coast (Rutllant et al. 1998, 2003). Ocean-atmosphere-land interactions are amplified around the capes and peninsulas like Punta Angamos (Rutllant et al. 1998, 2003), located at the northwesternmost point of the Mejillones Peninsula $\left(-70.52^{\circ} \mathrm{E},-23.04^{\circ} \mathrm{S} ;-70.40^{\circ},-23.54^{\circ}\right)$ (Fig. 1), resulting in enhanced coastal upwelling and ocean productivity (primary-productivity values measured within the bay have reached $138 \mathrm{mg} \mathrm{C} \mathrm{m}^{-3} \mathrm{~h}^{-1}$ (Rodríguez et al. 1991), while the annual production can reach $1070 \mathrm{~g} \mathrm{C} \mathrm{m}^{-2}$ (Marín et al. 1993)). The strong southerly winds also promote erosion and subsequent transport of mineral particles from the Pampa Mejillones, a flat desert surface located along the central-northern area of the peninsula, towards the homonymous bay (Fig. 1) (Flores-Aqueveque et al. 2009, 2010).
Together with the hyperaridity, this setting drives the accumulation of organic-rich biogenic marine sediments (TOC concentrations of $8.5 \%$ in the bottom of the bay (Valdés et al. 2009)) including eolian terrigenous particles on the sea floor (Vargas et al. 2004; Valdés et al. 2004), which can be used for high-resolution paleoceanographic reconstructions (Vargas et al. 2007).

\section{Methods}

Sampling and Sample Preparation.-The samples analyzed correspond to the material collected in the Mejillones Bay between September 25 and November 5, 2008, using marine sediment traps of 8:1 (length:diameter) ratio as recommended by Blomqvist and Håkansson (1981) and Bale (1998). Two identical systems were placed about $5 \mathrm{~km}$ from the shore $\left(23^{\circ}\right.$ $03^{\prime} 19^{\prime \prime} \mathrm{S}-70^{\circ} 27^{\prime} 28.9^{\prime \prime} \mathrm{W}$ ) at two different depths (27 and $\left.70 \mathrm{~m}\right)$ under the sea surface (Fig. 1).

The traps are plastic bottles of $1 \mathrm{~L}$ capacity filled with water of known salinity (40 psu) in which $1 \mathrm{ml}$ of $\mathrm{HgCl}_{2}$ was added to avoid bacterial proliferation. The traps were set up and collected by scuba divers.

In order to eliminate salt, the content of the bottles was washed after collection with deionized water (Wilde et al. 1970) and centrifuged at $4000 \mathrm{rpm}$ for three successive cycles of 25 minutes each. After this, the samples were dried, weighed, and separated approximately in two halves; one half was used in the size-distribution analysis.

The organic matter was dissolved by subjecting the sample to the action of $40 \mathrm{ml}$ of $\mathrm{H}_{2} \mathrm{O}_{2}(30 \%)$ solution (Kilmer and Alexander 1949). This mixture was heated at $60^{\circ} \mathrm{C}$ for several days until the organic matter was eliminated. After that, the sample was rinsed with deionized water following the same procedure as before.

To eliminate the residual biogenic silica (diatoms, spicules, etc.) and to avoid the dissolution of silica from clay minerals contained in the sediments, the remaining material was treated with $30 \mathrm{ml}$ of a $\mathrm{Na}_{2} \mathrm{CO}_{3}$ solution (1\%) and heated at $90^{\circ} \mathrm{C}$ for 3 hours (Conley and Schelske 2001). 
TABLE 1.-Number of particles and total weight before and after pretreatments.

\begin{tabular}{lccc}
\hline \hline Sample & $\begin{array}{c}\text { Particles } \\
\text { (units) }\end{array}$ & $\begin{array}{c}\text { Total Weight } \\
(\mu \mathrm{g})\end{array}$ & $\begin{array}{c}\text { Weight after Pre- } \\
\text { treatment }(\mu \mathrm{g})\end{array}$ \\
\hline T2 sup & 320882 & 59000 & 94.5 \\
T2 fon & 568163 & 54000 & 54.9 \\
T1 sup & 917209 & 74000 & 267.6 \\
T1 fon & 291006 & 52000 & 77.6 \\
\hline
\end{tabular}

To homogenize the mixture and facilitate the reaction, an ultrasonic shaking was applied every 30 minutes. Finally, the samples were repeatedly washed with deionized water and centrifuged at $4000 \mathrm{rpm}$ until the solution became almost neutral ( $\mathrm{pH}$ : 6-7) again.

Grain-Size Analyses and Data Treatment.-After pretreatment, the samples were analyzed with the Sysmex FPIA3000 (Malvern Instruments, in which FPIA stands for flow particle image analyzer) automated image analysis system. This system is based on a CCD (charge coupled device) camera that captures images of all the particles homogeneously suspended in an aqueous solution by rotation $(600 \mathrm{rpm})$ as they pass through the measurement cell. Thus, this system gives the size distribution and also displays images of the individual particles. If one ignores the images, this method provides size information comparable to that obtained with a laser granulometer and both methods can be compared to check the efficiency of the pretreatments.

After magnification $(\times 10)$ the images were automatically analyzed and several geometrical aspect criteria of the individual particles were determined: width (W), length (L), elongation (L/W), perimeter (P), surface $(\mathrm{S})$, convexity $(\mathrm{C})$, and equivalent spherical diameter $(\mathrm{d}$, defined as the diameter of the spherical particle having the same surface as the measured particle). Moreover, the optical density, or degree of blackness, was determined for every particle using the gray level on the scale of 0 256 used in the digitalization of the images ( 0 corresponds to pure black and 256 to pure white). As shown below, these morphological and optical parameters are essential to recognize and eliminate the particles of noneolian origin from the size distributions. Therefore, an original (nonfiltered) and a filtered (lithic particles only) size distribution can be obtained.

Due to the optical magnification, only particles with equivalent diameters between 0.5 and $200 \mu \mathrm{m}$ can be detected by this method. The whole measurement range is divided into 225 equal logarithmical steps. A log scale was chosen because the water-suspended sediment is assumed to be a mixture of several lognormally distributed particle populations (e.g., Brun-Cottan 1986). Because the size bins selected by the manufacturer are very narrow, the number of particles counted in some of them can be limited to just a few unities and, thus, the associated relative error can be important. In order to reduce errors we divided the number of size bins by a factor of five (we use 45 instead of the 225 original ones) and grouped the number of particles counted in each class. From these number counts, the mass of particles present in each size class was determined using the spherical assumption and the mass density of quartz $\left(2.65 \mathrm{~g} \mathrm{~cm}^{-3}\right)$. Then, we applied the iterative least-square method proposed by Gomes et al. (1990) to each mass distribution for determining the numerical characteristics (amplitude A, geometric mean diameter Gmd, and geometric standard deviation Gsd) of the individual lognormal populations whose combinations forms the overall size distribution.

Estimation of the Vertical Flux of Particles from the Size Analysis.Each sediment trap catches the particles settling in the water column. Thus, the size-resolved decantation flux can be estimated simply by dividing the mass of the collected particles in each size bin by the surface of the circular opening (diameter $=10.4 \mathrm{~cm}$ ) of the trap and by the duration of the collection period. A comparison of the total (nonfiltered) and the mineral (filtered) flux was performed to quantify the effectiveness of the pretreatments. In each case, the deconvolution procedure of Gomes et al. (1990) was also applied to the size-resolved fluxes for assessing the contribution of each individual particle population to the overall decantation flux.

\section{RESULTS AND DISCUSSION}

\section{Characteristics of the Original Samples}

In all the analyzed samples, the number of particles counted lies between 291,006 and 917,209 (Table 1). Although particles as large as $160.0 \mu \mathrm{m}$ were occasionally observed, the number of particles larger than $100.0 \mu \mathrm{m}$ usually amounts to a few units only. After taking into account that only a half of the original sample was analyzed, the conversion into mass of the number counts yields values of the total mass ranging between 54.9 and $267.6 \mu \mathrm{g}$ (Table 1). We used image analysis to check the efficiency of the pretreatments. As expected, most of the particles $(>58 \%)$ in each size class display the features typical of mineral grains. The main mineral species found were quartz and feldspar (Fig. 2A, B), amphiboles (Fig. 2C), and micas (Fig. 2D). This mineralogical composition is similar to the erodible fraction of the desert soils, and to the eolian particles moving across the pampa (Flores-Aqueveque et al. 2010).

Nonlithic particles can be sorted into three different categories: 1) particles of irregular aspect characteristic of organic matter (Fig. 2E), 2) very dark particles (Fig. 2F) probably of anthropogenic origin and produced by industrial activities (Valdés et al. 2004), and 3) non-dissolved diatoms (Fig. 2G) or other biogenic particles with a more elongated morphology (Fig. 2H, I). These nonlithic particles can be removed from the initial size distribution using various criteria based on the aspect of the particles as detailed in the following section.

\section{Removal of Nonmineral Particles}

The organic matter (Fig. 2E) was eliminated using the convexity (C) criterion. This parameter measures the surface roughness of the particle. It is calculated as the ratio of the area of the particle (A) to the area contained inside an imaginary ribbon tied around it $(\mathrm{A}+\mathrm{B})$ :

$$
\mathrm{C}=\mathrm{A} /(\mathrm{A}+\mathrm{B})
$$

$\mathrm{C}$ has values between 0 and 1 , and increases with the convexity of the particle. In practice, we decided to eliminate particles with $\mathrm{C}<0.8$ on the basis of the examination of many individual particles of organic matter. The number of particles removed varies between 1 and 710 (Table 2). All these particles have diameters between 2.2 and $95.2 \mu \mathrm{m}$ and represent from 0.04 to $33.2 \%$ of the original mass of the samples (Table 2).

The dark particles, i.e., those with the lowest intensity (Fig. 2F), were eliminated using the color criterion. The software calculates the mean "intensity" (I) of each photographed particle as the average of all the gray-scale values of its different pixels. After observing many particles, a threshold value of $\mathrm{I}=50$ was chosen to eliminate selectively the anthropogenic particles. This type of grain covers a larger range of diameters and was present in the four size modes defined previously. On average, it represents about $13.8 \pm 6.6 \%$ of the total mass (Table 2 ).

The particles recognized as biogenic silica (diatom fragments, spicules, etc.) (Fig. 2G, H, I) differ from the lithic ones by their more elongated (prolate) shape. Thus, these particles were eliminated on the basis of their width/length (W/L) ratio. The numerical threshold of elimination was arbitrarily fixed at $\mathrm{W} / \mathrm{L}<0.3$. The observation of the images of the removed particles revealed that together with nonlithic material some amphiboles had also been discarded by the automated procedure. These mineral particles were reintegrated manually into the size distribution. 

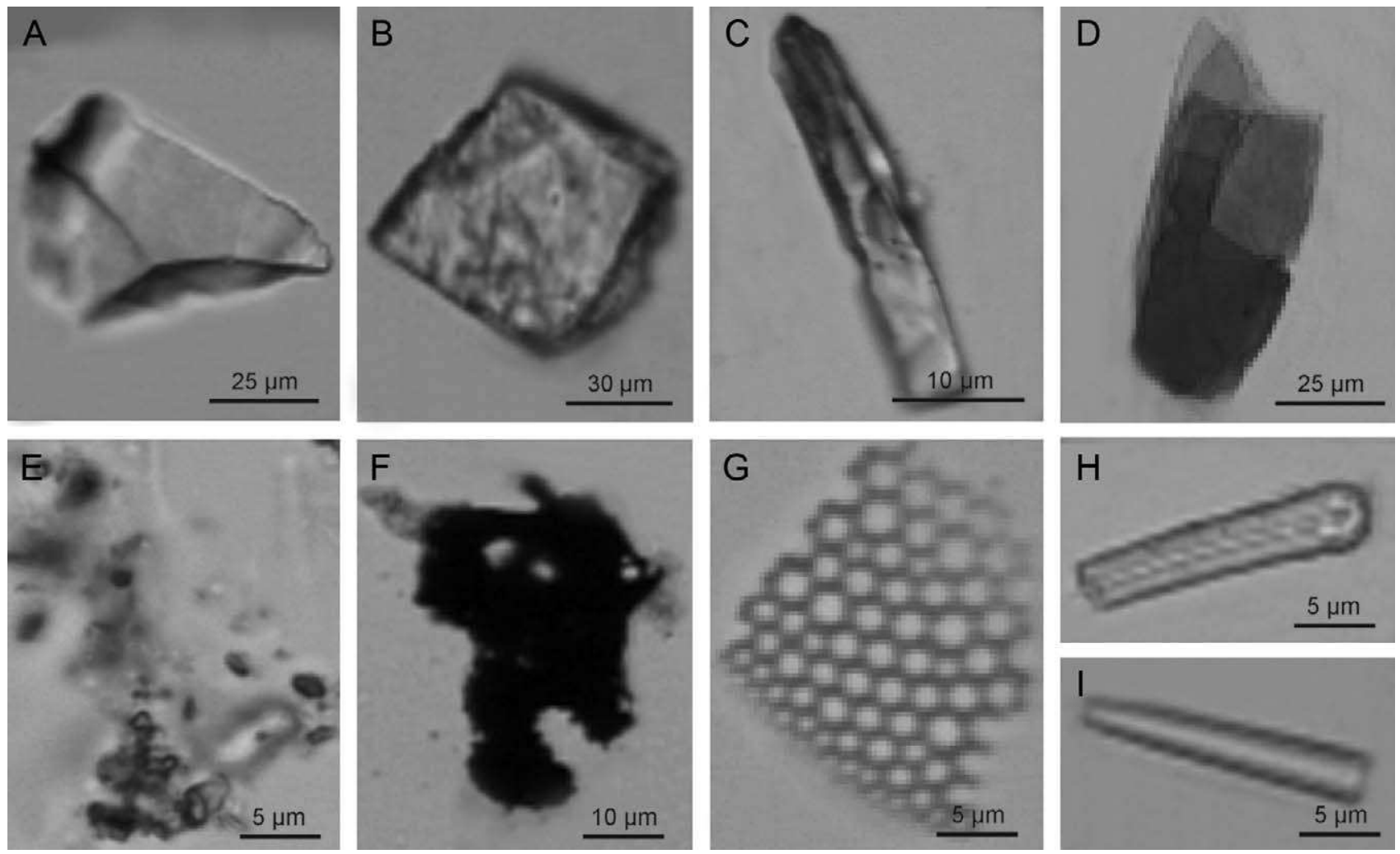

FIG. 2.-Examples of the various types and sizes of particles found in the analyzed samples. Photos A-D correspond to mineral particles. A, B) Quartz with equivalent diameters of 72 and $101 \mu \mathrm{m}$, respectively. C) Amphibole, $117 \mu \mathrm{m}$. D) Mica, $99 \mu \mathrm{m}$. E) Organic matter $(32 \mu \mathrm{m})$. F) Dark particles $(41 \mu \mathrm{m})$ of anthropogenic origin. G-I) fragments of biogenic silica with diameters of $22,2.5$, and $2.0 \mu \mathrm{m}$, respectively.

The particles eliminated using the $\mathrm{W} / \mathrm{L}$ criterion have equivalent diameters between 0.5 and $57.5 \mu \mathrm{m}$. They represent less than $1.7 \%$ of the initial mass of particles (Table 2).

In summary, the three types of nonmineral particles constituted between $<0.1$ and $33.2 \%$ of the initial mass of the samples (Table 2). In this fraction, the presence of the organic matter was much larger than the biogenic silica (33.2\% versus $1.7 \%$ ), indicating that the pretreatment used to remove organic matter was less effective than the one used to eliminate spicules and diatoms. The lack of application of a special treatment to remove the dark anthropogenic particles explains why their contribution to the total mass amounts to between 7.9 and $19.9 \%$, which makes it a significant component of the original samples.

These results corroborate that our method presents additional advantages as compared to other types of image-based size analyses (e.g., Beuselinck et al. 1998; Eshel et al. 2004; Frančišković-Bilinski et al. 2003; Konert and Vandenberghe 1997; Lira and Pina 2007; Vaasma 2008). The visual recognition tool and the possibility of eliminating nonlithic particles manually greatly improve the accuracy of the sizedistribution assessments.

\section{Size Distribution and Sedimentation Fluxes}

Original Nonfiltered Data.-For determining the main modes and their characteristics, the size distributions of the original (nonfiltered) data were analyzed with the deconvolution method of Gomes et al. (1990). All samples are represented by a mixture of at least four main modes, two very fine ones and two significantly coarser. The finest mode (Mode 1, Table 3 ) is centered at $2.0 \mu \mathrm{m}$. Its amplitude varies between 1.4 and $6.1 \mu \mathrm{g}$,

TABLE 2.-Amount, size-ranges and mass (total and \%) of the 3 types of nonlithic particles not removed by the pre-treatments intended to eliminate them from the collected samples. Identification of these particles was based on morphological characteristics of the individual particles (see text for details).

\begin{tabular}{|c|c|c|c|c|c|c|c|c|c|c|c|c|}
\hline \multirow[b]{3}{*}{ Sample } & \multicolumn{12}{|c|}{ Nonlithic Particles } \\
\hline & \multicolumn{4}{|c|}{ Organic Matter } & \multicolumn{4}{|c|}{ Dark Particles } & \multicolumn{4}{|c|}{$\mathrm{SiO}_{2}$ Biogenic } \\
\hline & $\begin{array}{c}\mathrm{N}^{\circ} \\
\text { Particles }\end{array}$ & $\begin{array}{l}\text { Size- } \\
\text { range }\end{array}$ & $\begin{array}{c}\text { Total Mass } \\
\quad(\mu \mathrm{g})\end{array}$ & $\%$ & $\begin{array}{c}\mathrm{N}^{\circ} \\
\text { Particles }\end{array}$ & $\begin{array}{l}\text { Size- } \\
\text { range }\end{array}$ & $\begin{array}{l}\text { Total Mass } \\
\qquad(\mu \mathrm{g})\end{array}$ & $\%$ & $\begin{array}{c}\mathrm{N}^{\circ} \\
\text { Particles }\end{array}$ & $\begin{array}{l}\text { Size- } \\
\text { range }\end{array}$ & $\begin{array}{c}\text { Total Mass } \\
\quad(\mu \mathrm{g})\end{array}$ & $\%$ \\
\hline T2sup & 97 & $4.9-43.0$ & 0.47 & 0.5 & 13 & $21.0-97.8$ & 7.42 & 7.9 & 2108 & $0.5-30.5$ & 0.21 & 0.2 \\
\hline T2fon & 1 & $20.5-22.8$ & 0.02 & 0.04 & 35 & $13.8-124.1$ & 10.95 & 19.9 & 4872 & $0.5-57.5$ & 0.95 & 1.7 \\
\hline T1sup & 51 & $7.3-77.0$ & 3.58 & 1.3 & 60 & $11.4-138.0$ & 50.95 & 19.1 & 6967 & $0.5-33.0$ & 0.89 & 0.3 \\
\hline T1fon & 710 & $2.2-95.2$ & 25.78 & 33.2 & 2 & $28.1-124.1$ & 6.61 & 8.5 & 2854 & $0.5-39.7$ & 0.33 & 0.4 \\
\hline Mean & 215 & & 7.46 & 8.8 & 28 & & 18.98 & 13.8 & 4200 & & 0.60 & 0.7 \\
\hline S.D. & 332 & & 12.31 & 16.3 & 26 & & 21.39 & 6.6 & 2183 & & 0.38 & 0.7 \\
\hline
\end{tabular}


TABLE 3.- Parameters (geometric mean diameter (Gmd), geometric standard deviation (Gsd) and amplitude (A)) of the 4 lognormal modes of the original (nonfiltered) samples, whose combination best fits the measured size distributions.

\begin{tabular}{|c|c|c|c|c|c|c|c|c|c|c|c|c|}
\hline \multirow[b]{2}{*}{ Sample } & \multicolumn{3}{|c|}{ Mode 1} & \multicolumn{3}{|c|}{ Mode 2} & \multicolumn{3}{|c|}{ Mode 3} & \multicolumn{3}{|c|}{ Mode 4} \\
\hline & Gmd $(\mu \mathrm{m})$ & $\mathrm{A}(\mu \mathrm{g})$ & Gsd & Gmd $(\mu \mathrm{m})$ & $\mathrm{A}(\mu \mathrm{g})$ & Gsd & Gmd $(\mu \mathrm{m})$ & A $(\mu \mathrm{g})$ & Gsd & Gmd $(\mu \mathrm{m})$ & $\mathrm{A}(\mu \mathrm{g})$ & Gsd \\
\hline T2sup & 2.0 & 1.4 & 1.5 & 8.0 & 7.2 & 2.0 & 33.0 & 8.5 & 1.4 & 72.0 & 60.9 & 1.4 \\
\hline T1fon & 2.0 & 1.4 & 1.5 & 10.0 & 11.2 & 2.0 & 37.0 & 10.7 & 1.4 & 83.0 & 56.3 & 1.4 \\
\hline
\end{tabular}

and its Gsd is equal to $1.5 \mu \mathrm{m}$ in all cases. The second fine mode (Mode 2, Table 3) has a Gmd in the 8.0-12.0 $\mu \mathrm{m}$ range and a more important amplitude $(\mathrm{A}=7.2-18.3 \mu \mathrm{g})$ than Mode 1. Its Gsd is also larger $(=2.0 \mu \mathrm{m})$ than Mode 1. Mode 3 (Table 3) is much coarser and narrower than the previous modes, with diameters between 33.0 and $42.0 \mu \mathrm{m}$, and Gsd = $1.4 \mu \mathrm{m}$ in all cases. Its amplitude is also quite variable, with values between 7.4 and $44.8 \mu \mathrm{g}$. The coarsest mode (Mode 4, Table 3) is between 70.0 and $120.0 \mu \mathrm{m}$. It is the most important mode in terms of mass, with amplitudes between 25.3 and $221.0 \mu \mathrm{g}$. In all the cases the standard deviation is Gsd $=$ $1.4 \mu \mathrm{m}$. It should be noted that the largest diameter value $(120.0 \mu \mathrm{m})$ of this mode was obtained only in the superficial trap during the second sampling period (T1sup). It presents the largest mass of the collected particles. However, this giant mode corresponds to only 20 particles with diameters above $100.0 \mu \mathrm{m}$. Note that "giant" particles were present in all samples, but usually in a very limited amount ( $<3$ units).

The calculated total flux of particles ranged between 364.9 and $1260.2 \mu \mathrm{g} \mathrm{day}^{-1} \mathrm{~m}^{-2}$, with the larger values achieved in the traps closest to the surface (Table 4). For the upper trap, the difference between the two sampling periods $(45 \%)$ is larger than the one $(10 \%)$ observed in the lower trap (Table 4).

The average contributions of Modes 1 and 2 to the overall flux are the lowest $\left(20.8 \pm 14.5\right.$ and $81.5 \pm 38.2 \mu \mathrm{g} \mathrm{day}{ }^{-1} \mathrm{~m}^{-2}$, respectively). For these two modes, the variability is about $70 \%$ and $47 \%$, respectively. The contribution of the two coarse modes is more important and also more variable than the fine modes. The individual flux of Mode 3 ranged between 50.4 and $210.7 \mu \mathrm{g}$ day ${ }^{-1} \mathrm{~m}^{-2}$ with a variability of $82 \%$, whereas Mode 4 contributed between 185.9 and $1040.4 \mu \mathrm{g}_{\text {day }}{ }^{-1} \mathrm{~m}^{-2}$ to the total flux with a variability of $80 \%$ (Table 4 ).

Comparison of the original flux with the one obtained adding the contributions of each individual mode shows that the deconvolution method largely reproduces the original size distribution. However, in most cases a slight (between $2 \%$ and $8 \%$ ) overestimation of the total flux is observed.

Lithic Particles.-The fitting method of Gomes et al. (1990) was applied again to the size distributions cleansed of their nonmineral fraction. Figure 3 illustrates an example of the deconvolution procedure applied to the size distributions measured for the samples collected at $27 \mathrm{~m}$

TABLE 4.- Values of the sedimentation fluxes for the 4 individual lithicparticle modes of nonfiltered samples.

\begin{tabular}{lrrrrrr}
\hline \hline & \multicolumn{5}{c}{ Fluxes $\left(\mu \mathrm{g} \mathrm{day}^{-1} \mathrm{~m}^{-2}\right)$} & \\
\cline { 2 - 5 } Sample & Mode 1 & Mode 2 & Mode 3 & Mode 4 & $\begin{array}{c}\text { Total } \\
\text { Modes }\end{array}$ & $\begin{array}{c}\text { Total } \\
\text { Original }\end{array}$ \\
\hline T2sup & 10.6 & 53.2 & 62.6 & 448.2 & 574.6 & 695.2 \\
T2fon & 37.3 & 133.7 & 54.1 & 185.9 & 410.9 & 404.1 \\
T1sup & 28.6 & 86.3 & 210.7 & 1040.4 & 1366.1 & 1260.2 \\
T1fon & 6.7 & 52.8 & 50.4 & 265.1 & 375.1 & 364.9 \\
Mean & 20.8 & 81.5 & 94.5 & 484.9 & & \\
S.D. & 14.5 & 38.2 & 77.7 & 386.3 & & \\
\% S.D. & $70 \%$ & $47 \%$ & $82 \%$ & $80 \%$ & & \\
\hline
\end{tabular}

and $70 \mathrm{~m}$ below sea level between October 10 and November 5, 2008 (T1 sup and $\mathrm{T} 1 \mathrm{fon})$. In these two cases as well as in the others not represented in Figure 3, the measured size distributions can be represented by a mixture of at most four lognormally distributed populations of particles whose parameters are reported in Table 5. The finest mode is characterized by a geometric mean diameter (Gmd) of $2.0 \mu \mathrm{m}$ (Mode 1) and presents a relatively narrow geometric standard deviation (Gsd $=$ $1.5 \mu \mathrm{m})$. The mass of particles of this mode varies between 0.9 and $6.0 \mu \mathrm{g}$. The second-finest mode has a Gmd between 7.0 and $11.0 \mu \mathrm{m}$ (Mode 2) and is broader than mode $1(\mathrm{Gsd}=2.0 \mu \mathrm{m})$. It represents a mass of particles between 7.1 and $21.1 \mu \mathrm{g}$. The third mode, which has a Gmd between 30.0 and $50.0 \mu \mathrm{m}$ (Mode 3), is also present in all samples. The corresponding mass varies between 6.2 and $44.3 \mu \mathrm{g}$. Finally, the coarsest mode (Mode 4) presents diameters in the 70.0-120.0 $\mu \mathrm{m}$ range, with masses between 14.6 and $151.1 \mu \mathrm{g}$. As was the case with the original (nonfiltered) size distribution, the larger particles $(120.0 \mu \mathrm{m})$ of Mode 4 are obtained only in the T1sup sample. After removal of nonlithic particles, the amount of this giant mode decreases to 14 particles.

The sedimentation fluxes calculated (in $\mu \mathrm{g} \mathrm{day}^{-1} \mathrm{~m}^{-2}$ ) for each mode are presented in Table 6. Comparing the results obtained at the two depths shows that the flux of particles for modes 1 and 2 is relatively independent of depth. Their average values are $17.8 \pm 12.3$ and $79.4 \pm$ $42.2 \mu \mathrm{g} \mathrm{day}^{-1} \mathrm{~m}^{-2}$, respectively, with a variability of $69 \%$ (given by the standard deviation) for mode 1 and $53 \%$ for mode 2 . These values are lower than the ones obtained for mode 3 (variability of $93 \%$ for an average of $87.3 \mu \mathrm{g} \mathrm{day}^{-1} \mathrm{~m}^{-2}$ ) and for mode 4 (variability of $82 \%$ for an average of $342.1 \mu \mathrm{g} \mathrm{day}^{-1} \mathrm{~m}^{-2}$ ).

This gives a total flux between 508.8 and $1047.6 \mu \mathrm{g} \mathrm{day}^{-1} \mathrm{~m}^{-2}$ for the upper trap, and between 237.2 and $313.3 \mu \mathrm{g}$ day ${ }^{-1} \mathrm{~m}^{-2}$ for the lower one. These results are consistent with the decrease of the particle flux with depth mentioned by Pace et al. (1987) and Buesseler et al. (2007). As observed in Table 6, the flux of particles accumulated in the upper trap during the second period is more than $50 \%$ larger than the one accumulated during the first period. In the lower trap, the difference between the two periods is only around $24 \%$. This difference could be due to the limited settling velocities of the particles in the water column. The particles falling into the bay will reach the upper trap relatively rapidly but the trap farther from the surface only after a delay. Similarly, the largest variability observed in the flux of the coarser modes $(>30.0 \mu \mathrm{m})$ can probably be explained by their large settling velocity and their short residence time in the water column. As a consequence of this, their concentrations are thought to be more closely linked to, and reflect better, the sporadic inputs of desert dust from the pampa than the sources for the finest particles (Mode 1 and Mode 2). Both observations agree with Siegel et al. (1990), whose analyses showed that large, rapidly sinking particles would be more representative of local conditions than the smaller, slowly sinking grains, which could be averaged over greater distances from the sampling site.

In this case also, comparison of the original fluxes with those estimated from the sum of the contributions of the individual modes indicates that the deconvolution method fits the filtered size distribution relatively well, since it underestimates by only $1 \%$ and $19 \%$ the fluxes of the first period (T2sup and T2fon; Sept. 25 to Oct.10, 2008), and overestimates the fluxes 


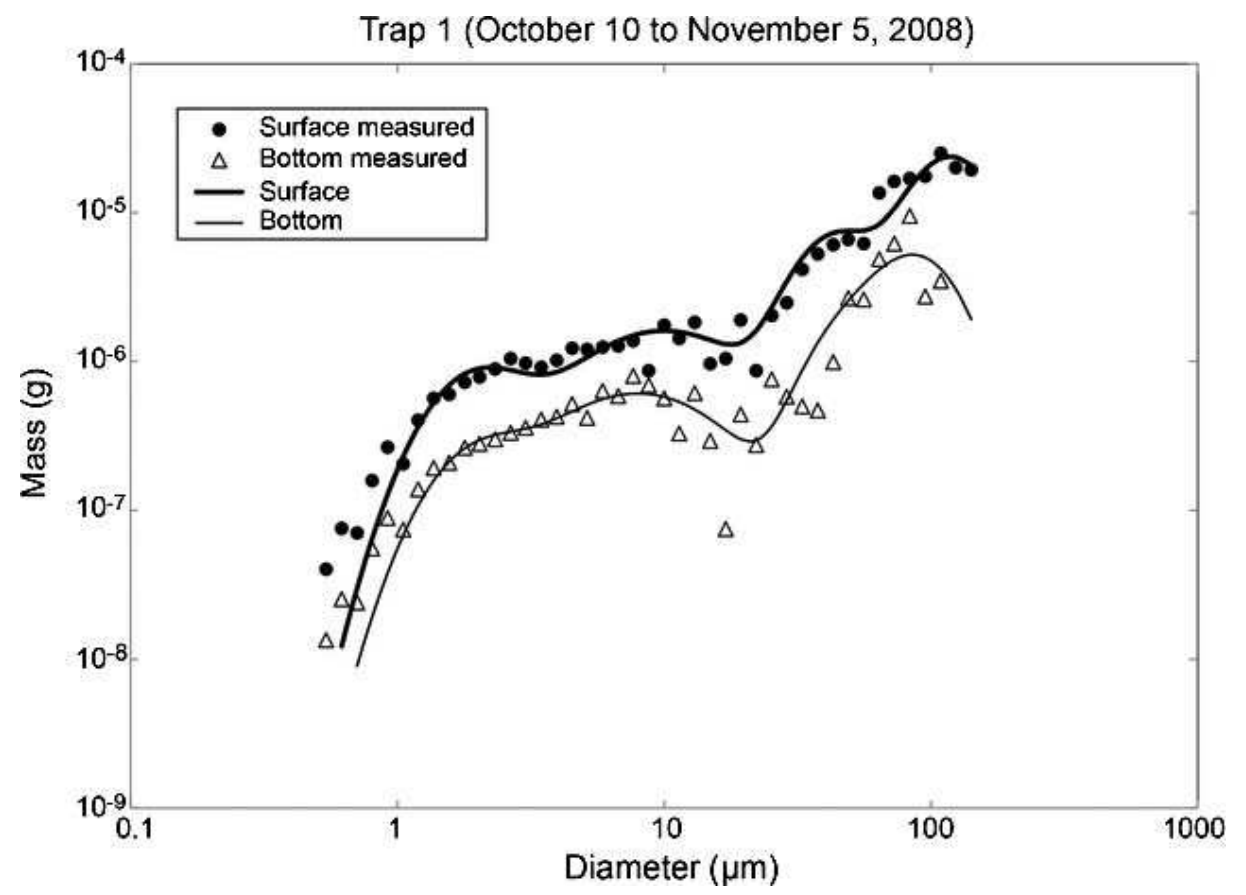

FIG. 3.-Deconvolution results of the measured size distribution for the lithic fraction of the samples collected during Oct. 10 and Nov. 5, 2008. of the second period (T1sup and T1fon; Oct. 10 to Nov. 5, 2008) by only $5 \%$ and $12 \%$, respectively.

\section{CONCLUSION}

By comparing the results of both methods it can be observed that after removal of the nonlithic particles the particle modes remain in the same size ranges, especially the two finest modes. In general, filtering of the size distributions leads to a decrease in the mass (amplitude) of the size modes. This decrease, which is more significant in the case of the two coarse modes, is particularly remarkable for Mode 4 . In this case, the lowering of the contribution is directly due to the elimination of the anthropogenic dark particles, whereas in the case of Mode 3 this decrease is associated with the combined removals of the dark particles and of the organic matter. Despite its frequent occurrence, the presence of residues of biogenic silica (2108 to 6967 units; Table 2) does not seem to modify the size distribution importantly because of their very fine diameters and, consequently, low mass.

The estimated fluxes are also influenced by the changes in the amplitude of the size modes resulting from the filtering. A decrease was observed in most of the cases, indicating that, with values between 13\% and $58 \%$ above the corrected ones, use of nonfiltered size distributions generally leads to an important overestimation of the fluxes. This overestimation is also due to the assumption that all particles have the same density (i.e., quartz), which in the case of nonlithic particles might constitute a gross overestimation.
These results also indicate that some of the pretreatments used to remove nonlithic particles are not as efficient as expected. Analysis of the content of the original samples in nonlithic particles shows that the occurrence of biogenic silica is low, almost systematic, and roughly constant $(0.7 \%$ of variation) in all the samples. Thus, their presence could be properly predicted and estimated for this type of sample. In contrast, the large variability $(16.3 \%)$ of the content of residual organic matter not only evidences the low efficiency of the protocols, which should be reviewed and modified, but it also excludes the possibility of using a systematic correction of the fluxes derived from the nonfiltered size distributions. Finally, the observation of dark particles in the samples was unexpected. For lack of an appropriate chemical removal treatment, imaging is the only practical way available for discriminating these dark particles from the lithic ones. Therefore, image-based size analysis seems to be an accurate technique allowing determination of the size distribution and flux of this type of fine sediments. More generally, it is a powerful tool for: 1) controlling, adapting, and improving the removal protocols of biogenic silica and organic matter, 2) recognizing unexpected particles which cannot be pretreated, and 3) correcting the particulatematter size distribution of the presence of these particles.

\section{ACKNOWLEDGMENTS}

This investigation was carried out within the framework of an international scientific collaboration between the University of Chile (Department of Geology and Department of Geophysics), the University of Antofagasta

TABLE 5.-Parameters (geometric mean diameter ( Gmd), geometric standard deviation ( $G s d)$ and amplitude (A)) of the 4 lognormal modes of the lithic fraction of the samples, whose combination best fits the measured size distributions.

\begin{tabular}{|c|c|c|c|c|c|c|c|c|c|c|c|c|}
\hline \multirow[b]{2}{*}{ Sample } & \multicolumn{3}{|c|}{ Mode 1} & \multicolumn{3}{|c|}{ Mode 2} & \multicolumn{3}{|c|}{ Mode 3} & \multicolumn{3}{|c|}{ Mode 4} \\
\hline & Gmd $(\mu \mathrm{m})$ & $\mathrm{A}(\mu \mathrm{g})$ & Gsd & Gmd $(\mu \mathrm{m})$ & $\mathrm{A}(\mu \mathrm{g})$ & Gsd & Gmd $(\mu \mathrm{m})$ & $\mathrm{A}(\mu \mathrm{g})$ & Gsd & Gmd $(\mu \mathrm{m})$ & $\mathrm{A}(\mu \mathrm{g})$ & Gsd \\
\hline T2sup & 2.0 & 0.9 & 1.5 & 7.0 & 7.1 & 2.0 & 30.0 & 6.2 & 1.4 & 70.0 & 54.9 & 1.4 \\
\hline T1fon & 2.0 & 1.6 & 1.5 & 8.0 & 8.0 & 2.0 & 50.0 & 9.9 & 1.4 & 90.0 & 30.9 & 1.4 \\
\hline
\end{tabular}


TABLE 6.-Values of the sedimentation fluxes for the 4 individual lithicparticle modes of the lithic fraction.

\begin{tabular}{lrrrrrr}
\hline \hline & \multicolumn{5}{c}{ Fluxes $\left(\mu \mathrm{g} \mathrm{day}^{-1} \mathrm{~m}^{-2}\right)$} & \\
\cline { 2 - 5 } Sample & Mode 1 & Mode 2 & Mode 3 & Mode 4 & Total Modes & Total Lithic \\
\hline T2sup & 6.7 & 52.1 & 45.9 & 404.1 & 508.8 & 630.5 \\
T2fon & 28.6 & 128.9 & 48.1 & 107.7 & 313.3 & 316.4 \\
T1sup & 28.4 & 99.1 & 208.5 & 711.6 & 1047.6 & 998.2 \\
T1fon & 7.6 & 37.6 & 46.7 & 145.3 & 237.2 & 211.4 \\
Mean & 17.8 & 79.4 & 87.3 & 342.1 & 526.7 & \\
S.D. & 12.3 & 42.2 & 80.8 & 279.3 & 365.6 & \\
\% S.D. & $69 \%$ & $53 \%$ & $93 \%$ & $82 \%$ & $69 \%$ & \\
\hline
\end{tabular}

(Faremar), the University of Paris XII and Paris-Diderot (LISA), and IRD (PALEOTROPIQUE), favored by the ECOS-CONICYT \#C05U03 cooperation project. Field experiments and data acquisition were funded by project Fondecyt 11060484 . Additional funds were provided by project Fondecyt 11121543 and project JEAI LASPAL, from the IRD-University of Antofagasta-University of Chile cooperation program. We are especially grateful to Dr. John Gillies, Dr. Tiit Vaasma, Dr. Todd Caldwell, Dr. James MacEachern, and John B. Southard for their valuable comments on the manuscript, which helped to improve the readability of this text. We also thank R. Melon, A. Turbina, and M. Trejo.

\section{REFERENCES}

BALE, A.J., 1998, Sediment trap performance in tidal waters: comparison of cylindrical and conical collectors: Continental Shelf Research, v. 18, p. 1401-1418.

Beuselinck, L., Govers, G., Poesen, J., Degraer, G., and Froyen, L., 1998, Grain-size analysis by laser diffractometry: comparison with the sieve-pipette method: Catena, $\mathrm{v}$. 32, p. 193-208.

BlomQvist, S., AND HåkansSon, L., 1981, A review on sediment traps in aquatic environments: Archiv für Hydrobiologie, v. 91, p. 101-132.

BRUN-CotTAN, J.C., 1986, Vertical transport of particles within the Ocean, in BuatMénard, P., ed., the Role of Air Sea Exchange in Geochemical Cycling: Dordrecht, Reidel, NATO ASI Series, v. 185, p. 83-111.

Buesseler, K.O., Antia, A.N., Chen, M., Fowle, S.W., Gardner, W.D., Gustafsson, O., Harada, K., Michaels, A.F., Van Der Loeff, M.R., Sarin, M., Steinberg, D.K., AND TRULL, T., 2007, An assessment of the use of sediment traps for estimating upper ocean particle fluxes: Journal of Marine Research, v. 65, p. 345-416.

Buurman, P., Pape, T., Reijneveld, J.A., De Jong, F., and Van Gelder, E., 2001, Laser-diffraction and pipette-method grain sizing of Dutch sediments: correlations for fine fractions of marine, fluvial, and loess samples: Netherlands Journal of Geoscience, v. 80, p. 49-57.

Conley, D.J., AND Schelske, C.L., 2001, 14. Biogenic silica, in Smol, J.P., Birks, H.J.B. and Last, W.M., eds., Tracking Environmental Change Using Lake Sediments, Volume 3: Terrestrial, Algal, Siliceous Indicators: Dordrecht, The Netherlands, Kluwer Academic Publishers, p. 281-293.

Eshel, G., Levy, G.J., Mingelgrin, U., And Singer, M.J., 2004, Critical evaluation of the use of laser diffraction for particle-size distribution analysis: Soil Science Society of America, Journal, v. 68, p. 736-743.

Flores-Aqueveque, V., Vargas, G. Rutllant, J, and Le Roux, J.P., 2009 Parametrización, estacionalidad y sedimentología del transporte eólico de partículas en el desierto costero de Atacama, Chile $\left(23^{\circ} \mathrm{S}\right)$ : Andean Geology, v. 36, p. 288-310.

Flores-Aqueveque, V., Alfaro, S., Muñoz, R., Rutllant, J., Caquineau, S., Le Roux, J., AND Vargas, G., 2010, Aeolian erosion and sand transport over the Mejillones Pampa in the coastal Atacama Desert of northern Chile: Geomorphology, v. 120, p. 312-325.

FrančišKović-Bilinski, S., Bilinski, H., Vdović, N., Balagurunathan, Y., and Dougherty, E.R., 2003, Application of image-based granulometry to siliceous and calcareous estuarine and marine sediments: Estuarine, Coastal and Shelf Science, v. 58 , p. $227-239$
Gomes L., Bergametti, G., Coudé-Gaussen, G., and Rognon, P., 1990, Submicron desert dusts: a sandblasting process: Journal of Geophysical Research, v. 95, p. 13927 13935

Kilmer, V.J., And Alexander, L.T., 1949, Methods of making mechanical analyses of soils: Soil Science, v. 68 , p. 15-24.

Konert, M., AND Vandenberghe, J., 1997, Comparison of laser grain-size analysis with pipette and sieve analysis: a solution for the underestimation of the clay fraction: Sedimentology, v. 44, p. 523-535.

Krumbern, W.C., 1942, Settling velocity and flume behavior of non-spherical particles: American Geophysical Union, Transactions, v. 41, p. 621-633.

LiRA, C., AND PINA, P., 2007, Granulometric and morphometric characterization of sand grains, Rio de Janeiro, 8th International Symposium on Mathematical Morphology, Oct. 10-13, Proceedings, v. 2, p. 73-74.

Marín, V., Rodríguez, L., Vallejo, L., Fuenteseca, J., and Oyarce, E., 1993, Efectos de la surgencia costera sobre la productividad primaria primaveral de la Bahía Mejillones del Sur (Antofagasta, Chile): Revista Chilena de Historia Natural, v. 66, p. 47-491.

Marín, V., And Olivares, G.R., 1999, Estacionalidad de la productividad primaria en Bahía Mejillones del Sur (Chile): una aproximación proceso-funcional: Revista Chilena de Historia Natural, v. 72, p. 629-641.

Marín, V., Delgado, L.E., And Escribano, E., 2003, Upwelling shadows at Mejillones Bay (northern Chilean coast): a remote sensing in situ analysis: Investigaciones Marinas, Valparaíso, v. 31, p. 47-55.

Matthews, M.D., 1991, The effect of grain shape and density on size measurement, in Syvitski, J.P.M., ed., Principles, Methods and Application of Particle Size Analysis: Cambridge, U.K., Cambridge University Press, p. 22-33.

MuÑoz, R.C., 2008, Diurnal cycle of surface winds over the subtropical southeas Pacific, Journal of Geophysical Research, v. 113, D13107, doi: 10.1029/ 2008JD009957.

Pace, M.L., Knauer, G.A., Karl D.M., and Martin, J.H., 1987, Primary production, new production and vertical flux in the eastern Pacific Ocean: Nature, v. 325, p. 803 804.

Rodriguez, L., Marin, V., Farias, M., and Oyarce, E., 1991, Identification of an upwelling zone by remote sensing and in situ measurement, Mejillones del Sur Bay (Antofagasta, Chile): Scientia Marina, v. 55, p. 467-473.

Rutllant, J., Fuenzalida, H., Torres, R., and Figueroa, D., 1998, Interacción océano-atmósfera tierra en la Región de Antofagasta (Chile, $23^{\circ} \mathrm{S}$ ): Experimento DICLIMA: Revista Chilena de Historia Natural, v. 71, p. 405-427.

Rutllant, J., Fuenzalida, H., And Aceituno, P., 2003, Climate dynamics along the arid northern coast of Chile: the 1997-1998 Dinámica del Clima de la Región de Antofagasta (DICLIMA) experiment: Journal of Geophysical Research, Atmospheres, v. 108, 4358, doi: 10.1029/2002JD003357.

Siegel, D.A., Granata, T.C., Michaels, A.F., and Dickey, T.D., 1990, Mesoscale eddy diffusion, particle sinking, and the interpretation of sediment trap data: Journal of Geophysical Research, v. 95, p. 5305-5311.

Strub, T., Mesías, J., Montecino, V., Rutllant, J., and Salinas, S., 1998, Coastal ocean circulation off western South America, in Robinson, A.R., and Brink, K.H., eds., The Sea, Volume 11: New York, J. Wiley and Sons, p. 273-313.

VAasma, T., 2008, Grain-size analysis of lacustrine sediments: a comparison of pretreatment methods: Estonian Journal of Ecology, v. 57, p. 231-243.

Valdés, J., Sifeddine, A., Mariano, C., and Ortlieb L, 2004, Partículas de carbón en sedimentos marinos de la bahía Mejillones del Sur $\left(23^{\circ} \mathrm{S}\right)$ : implicancias ambientales en un contexto histórico: Investigaciones Marinas, Valparaíso, v. 32, p. 93-99.

Valdés, J., Sifeddine, A., Ortlieb, L., And Pierre, C., 2009, Interplay between sedimentary organic matter and dissolved oxygen availability in a coastal zone of the Humboldt Current System; Mejillones Bay, northern Chile: Marine Geology, v. 265, p. $157-166$

Vargas, G., Ortlieb, L., Pichon, J.J., Bertaux, J., and Pujos, M., 2004, Sedimentary facies and high-resolution primary production inferences from laminated diatomaceous sediments off northern Chile $\left(23^{\circ} \mathrm{S}\right)$ : Marine Geology, v. 211, p. 79-99.

Vargas, G., Pantoja, S., Rutllant, J., Lange, C., and Ortlieb, L., 2007, Enhancement of coastal upwelling and interdecadal ENSO-like variability in the Peru-Chile Current since late 19th century: Geophysical Research Letters, v. 34, L13607, doi: 10.1029/ 2006 GL0288127.

Wilde, P., Holden, J., ANd Isselhardt, C., 1970, Non-destructive wet weighing of marine sediments: Marine Geology, v. 8, p. 173-178.

Received 12 July 2013; accepted 3 December 2013. 